\title{
Reviewing Restorative Principles of Corporate Punishment in Corruption Crime
}

\author{
Rizal F, ${ }^{*}$ Andi Muhammad Sofyan, Abrar Saleng, Anwar Borahima \\ Faculty of Law, Hasanuddin University, South Sulawesi, Indonesia
}

\begin{abstract}
The corporation as an entity or legal subject whose existence contributes greatly in increasing economic growth and national development. However, as it turns out into practice, the corporation sometimes also commit criminal acts that have a bad impact on the State and society. The research is a qualitative research based on normative or doctrinal legal methods. The results show that the reparative value as contained in corruption crime acts for corporations is still limited to additional penalties, namely substitute money. In practice, it is not effective, a more progressive punishment is needed that can effectively restore the original state of the impact of the corruption crime. The principle of restorative is a reparative justice, encounter conception, and transformative conception. Reparative justice or recovery to the victims or recovery to the consequences incurred of a criminal offense. Encounter conception is a way or process, to realize transformative conception, to achieving a just society by understanding the needs of all parties. The essence of reparation as a basic principle of restorative justice in corruption crime is to restore balance, the recovery of damage incurred due to corruption, so it needs to be formulated as an alternative additional penalty besides the restitution in the future.
\end{abstract}

Keywords: Corporate; Corruption; Restorative; Reparative

DOI: $10.7176 / J L P G / 88-23$

Publication date: August $31^{\text {st }} 2019$

\section{Introduction}

People welfare becomes a main basis for every policy-making to improve the standard of living as a constitutional right of every Indonesian citizen. ${ }^{1}$ In this context, law must take its role in the realization of national objectives as stipulated in the constitution. Law and law-enforcement will be the main tools to control social changes, in line with developments in society.

Nowadays, to realize the people's welfare is faced with the problem of high corruption in Indonesia. After a long time of law-enforcement in eradicating corruption, there has not been a significant change in the cultural character of society towards corruption. We always hear every day about the judicial process by the police, prosecutors and Corruption Eradication Commission.

Observing various types of criminal offense that can be categorized as corruption, it surely that the consequences are also varied. Seen from the time of occurrence, the consequences arising from corruption can be felt directly at that time and indirectly it can be felt immediately, and those that can only be felt after a certain period of time. ${ }^{2}$ One of the consequences of corruption by inhibits development, neglect of infrastructure development, disrupting the people's interests and unstable economy.

In 2017 for example, the amount of restitution of State's losses as result of the implementation of decisions by the Prosecutor and the Corruption Eradication Commission is still far from the amount of losses incurred due to corruption crime. As the amount of State's loss found by the Police and Investigator by IDR 7.000.000.000.000 (seven trillion rupiah), it can only be restituted in the amount of approximately IDR 977.279.282.159.45 or not reaches $15 \% .^{3}$ Restitution as result of corruption through the substitution money has not been restituted maximally to the State. ${ }^{4}$ In 2014, the Indonesia Corruption Watch records the restitution of State losses was only one-fifth of total State losses.

Several data as presented above shows that the handling of cases that have been performed so far, from the three agencies i.e the Police, the Attorney and the Corruption Eradication Commission have not been effective in restitute the State losses as the essence of eradicating corruption crime. It is ineffective because the restitution of State losses as realized from the results of the implementation of the Judge's decision by the Public Prosecutor is still far from the amount of State losses by corruption.

Seeing the corporation as an entity or legal subject whose existence contributes greatly in increasing economic growth and national development. However, as it turns out into practice, the corporation sometimes

\footnotetext{
${ }^{1}$ Sharfudin, 2009, "Pelaksanaan Politik Hukum Pidana dalam Penegakan Hukum Pidana di Indonesia”, Jurnal Hukum Pro Justitia Vol. 27 No.2, p. 177

${ }^{2}$ Kristina, 2016, Pemberantasan Tindak Pidana Korupsi (Perspektif Hukum Progresif), Yogyakarta: Thafa media, p.33

${ }^{3}$ Source: Kriminologi. Available online at: https://kriminologi.id/hard-news/korupsi/kejagung-selamatkan- kerugian-negara-rp-977-miliarsepanjang-2017, downloaded on 7 Juli 2018

${ }^{4}$ Indonesia Corruption Watch, 2015, Naskah akademik dan Rancangan Undang-Undang tentang Pemberantasan Tindak Pidana Korupsi, Jakarta, p. 29
} 
also commit criminal acts (corporate crime) that have a bad impact on the State and society. In addition, the corporation can a place to hide assets resulting from criminal acts that are not touched by the legal process in criminal liability.

In terms of eradicate corruption with the subject of corporate law; the penalties imposed namely fines or restitution, in which they have not been effectively responsive in protecting the interests of victims of corruption i.e the State and society. This is evidenced by the impact of corruption committed by corporations such as in the procurement of construction work that is not implemented or there are no benefits felt by the State or society, should the community can use facilities or infrastructure for smoothing the community's economy, but because corporate actions commit corruption so that no benefit is received by the community, even though the State has spent funds for development.

For this reason, it is necessary to rethink the handling of cases or corruption crime with responsive and equitable corporate law subjects so that the interests of the State and society are protected, effectively restoring the original state, restoring development and the economy. It was done because the company felt worried for its actions and wanted the local community to immediately restore the original state. In addition, the company has moral burdens to protect their workers in which they rely on the company and worried about their survival.

A progressive legal thinking aimed at bringing people to prosperity and happiness, when faced with a problem, then the law must be reviewed and corrected rather than being forced to be included in the existing legal scheme, ${ }^{1}$ and the basic principle of restorative is reparative as focus of research.

\section{Method of Research}

The research is a qualitative research based on normative or doctrinal legal methods. ${ }^{2}$ It uses a conceptual, case, and comparative approach. The sites of research were conducted at the Supreme Court of the Republic of Indonesia, the Corruption Court at the District Court of Bengkulu and Majene. In addition, it was also conducted on the officials of the Attorney General Office of the Republic of Indonesia namely the Junior Attorney General for Special Crimes, the District Attorney of Majene in West Sulawesi, and the District Attorney of Seluma in Bengkulu.

\section{Examining Reparative Values and Progressive Law in Handling Corruption Crimes to Corporation}

It is different from the subject of individual law, corporations have organs outside of their own souls, namely workers who are not involved in the will of the corporation that is run by the management, but when the corporation is convicted, these workers will also feel the suffering of punishment. Fines as main punishment imposed on corporations has similar purpose to the basic prison penalties imposed on people, namely to inflict suffering, if body punishment (imprisonment) on people gives suffering because their movement are restricted, then the fines penalties for corporations gives suffering to corporate body. Thus, the principal fines imposed on corporations according to the author are not effective as a form of penalties to restore State's losses or the economy.

Furthermore, additional penalties imposed on corporations in which its essence to recover or restore State's losses or economy, is it effective in achieving its goal? Losses can be in the form of damage to public facilities, bridges that should be enjoyed by the community as a link to the economy but because corruption is broken up, hospital medical devices that should be enjoyed by patients become not fulfill the standard so that they are not used due to corruption, schools used by children to learn to collapse due to corruption.

State losses incurred are estimated by State loss counting experts as requested by the public prosecutor and then submitted to the court both stated in the indictment and then the expert is invited to provide information before the panel of judges. The losses submitted are stated in the indictment letter of Public Prosecutor and decided by the judges so that the defendant pays compensation as intended. The punishment was executed by the public prosecutor by entering into the State treasury as restitution from the defendant. The money then goes into the State treasury, then what about the damage caused by corrupt acts from the corporation? Does the restitution of money into the State treasury the damage can be recovered? What a bridge that was previously broken can be rebuilt immediately to connect the economy? Or medical devices can be immediately used by doctors to treat patients? Or children can immediately learn quietly in a sturdy school building? Certainly, cannot be so.

So far, prosecution as performed has a reparative value in the form of additional penalties, namely restitution, the amount of restitution is obtained from the opinion of the public prosecutor regarding the amount of losses (nominalized in money value) caused by damage due to a criminal crime committed by the defendant of corporation, this criminal is expected to recover State's financial or economic losses caused by corruption.

The Attorney General of the Republic of Indonesia has made efforts to investigate and prosecute corporate

\footnotetext{
${ }^{1}$ Moh. Mahfud MD, Sunaryati Hartono, Sidharta, Bernard L. Tanya, Anton F. Susanto, 2013 Dekonstruksi dan Gerakan Pemikiran Hukum Progresif (Inaugural Speech Dr. Niken Savitri, SH, MCL; Teori Hukum Feminis dan Hukum Progresif), Yogyakarta : Tafa Media, p. 129.

${ }^{2}$ Johny Ibrahim, 2006, Teori dan Metodologi Penelitian Hukum Normatif, Malang: Bayumedia, p.34
} 
legal subjects involved in corruption. Based on data obtained from the results of the research, the following cases have been handled by the Attorney General of the Republic of Indonesia (table 1).

Table 1. Data the handling of corruption to corporations by the Attorney General of the Republic of Indonesia

\begin{tabular}{clc}
\hline No & \multicolumn{1}{c}{ Name of Corporation } & Year \\
\hline 1 & PT. Indosat dan PT. Indosat Mega Media (PT. IM2) & 2013 \\
2 & PT. Giri Jaladhi Wana (PT. GJW) & 2011 \\
3 & PT. Puguk Sakti Permai (PT. PSP) & 2018 \\
4 & PT. Beringin Bangun Utama (PT. BBU) & 2017 \\
5 & PT. Putra Papua Perkasa (PT. PPP) & 2018 \\
6 & PT. Kakas Karya & 2018 \\
7 & PT. Proxima Convex & 2016 \\
8 & PT. Fatimah Indah Utama (PT. FIU) & 2016 \\
9 & PT. Karya Putra Tunggal Jaya (PT. KPTJ) & 2016 \\
\hline
\end{tabular}

Source: Primary data, 2019 (edited).

As research findings for handling corruption to corporations, the researcher argues that the State losses incurred are estimated by the State loss counters as asked by the prosecutor in the trial to provide information. The losses were stated in the indictment of the prosecutor and it was decided by the judges that the defendant pay restitution as intended. The punishment was executed by the public prosecutor by entering restitution into the State treasury as obtained from the corporation as defendant.

Also, the researcher gives an example PT. Fatimah Indah Utama related to the corporation corruption as discussed earlier, this corruption was carried out in 2012 which resulted in the collapse of Palipi Archipelago Fisheries Port revetment so that the fishery activities at the port could not function optimally as expected, even after this case, PT. Fatimah Indah Utama has already paid the restitution, but in reality since the writing of this dissertation, the fishery port is not function optimally.

The restitution deposited into the state treasury is included as non-tax State revenue from the Attorney General of the Republic of Indonesia, the funds are mixed and do not necessarily be used for damaged construction by corruption. Reconstruction must be budgeted again and it through the bureaucratic process and requires a long time, and also to budget with the same development the budget will be greater than the previous budget, because of rising prices of building materials.

According to the researcher, if depart from the essence of corruption crime that aimed to recover the State losses or economy, it is necessary to conduct a recent discussion of the punishment system applied to corporations in corruption. In an example PT. Fatimah Indah Utama as previously mentioned that the corruption was carried out in 2012 which resulted in the collapse of Palipi Archipelago Fisheries Port revetment so that the fishery activities at the port could not function optimally as expected, even after this verdict in 2017, the defendant has already paid the restitution, but in reality, since the writing of this dissertation, the fishery port is not function optimally.

A reparative value as one of the basic principles of restorative justice can actually be a solution to this problem. The immediate recovery of the situation could be the objective of punishment, namely fairness for the victim and the corporation.

\section{Reparative Approach in Criminal Law: A Comparative Study}

In essence, a restorative justice approach is an effort to resolve a criminal case that emphasizes on recovery to the conditions before the crime or that should have occurred if the crime was not committed. By the recovery of losses due to crime, it is expected to rebuild the harmony of life as before crime. This approach has been widely practiced in various countries, not only in indigenous peoples, but also in the modern criminal justice system. ${ }^{1}$ As a comparison, the following practices are described in various countries related to the restorative justice approach in the resolution of criminal cases, especially with the subject of corporate law.

a. United States

As cited in Holten, NG., and Lamar, LL, ${ }^{2}$ In US, the public prosecutors are permitted not to prosecute, including if:

1) Potency of danger if prosecution is done against the defendant

2) Available choices other than prosecution

3) The defendant is willing to become a justice collaborator

4) Limited resources for prosecution

5) The capacity of the court

\footnotetext{
${ }^{1}$ Muhammad Irwan, Slamet Sampurno Soewondo, M. Syukri Akub, Wiwie Heryani. 2018. The Role of Judges in Realizing Justice: A Criminal Justice Perspective. Journal of Law, Policy and Globalization, Vol. 76, 114.

${ }^{2}$ Bambang Waluyo, 2016, Penegakan Hukum di Indonesia, Jakarta ; Sinar Grafika, p.178
} 
In the practice of handling criminal cases in the United States, it is recognized by the existence of Plea Bargaining (PB) is a resolution of disputes using mediation. ${ }^{1}$ In the "Federal Rules of Criminal Procedure" (rule 11) we do not find explicitly the boundary of PB. However, the regulation has stipulated the procedures for implementing PB. In paragraph (e) rule $11^{2}$ is clearly applied to the scope of PB and therefore reflects a boundary.

Based on some of the PB restrictions, it can be concluded as follows: ${ }^{3}$

1) In essence, $\mathrm{PB}$ is a negotiation between the public prosecutor and the accused or their defense;

2) Main motivation for negotiation is to accelerate the process of handling criminal cases;

3) The character of negotiations must be based on the volunteerism of the accused to admit his/her mistakes and the willingness of the public prosecutor to provide the punishment as wanted by the defendant or their defense.

4) Participation of judges as impartial referees in the negotiations is not permitted.

According to the researcher, PB system also has a restorative spirit, by the desire to resolve disputes with forgiveness and restore the situation or balance between the offender and the victims. Granting policies to offender of crime to recovered.

\section{b. France}

France is a country that adopts a civil law system which has given legal authority to resolve a crime through mediation known as Victim-Offender Mediation (VOM) ${ }^{4}$ In the Criminal Code of France, it has indirectly granted the right to a panel judges) to encourage negotiation for the settlement at the stage of punishment to the offender.

Article 41 of the Criminal Code of France stipulates that mediation process can only be done at the stage of pre-prosecution or in other words the mediation is a diversion from the prosecution process. However, whatever the results and impacts arising from the mediation process, the prosecutor will use his right of discretion to make a decision on peace or prosecute if an agreement is not reached. Providing assistance or recovery can be done after the consent of the victim through a dialogue with the perpetrator, his/her parents, as well as authorized representative bodies and responsible for it. ${ }^{5}$

The level of mediation that often conducted by mediators consisting of several stages, the first is the preliminary stage by exchange the information between the prosecutor and the association, conflict analysis, and then followed by a preliminary meeting with the parties. The second stage is the mediation process; the third stage is the agreement process as outlined in an agreement between victims and perpetrators. And the fourth stage includes the implementation, termination of mediation or cases and evaluation.

According to the researcher, the application of restorative justice in France's legal system, illustrates that France has provided an alternative effort to the community in resolving legal issues so that it can be efficient and reduce State's cost, restoration of the condition that can be a purpose of the criminal law that wants to be applied to the community in resolving criminal dispute.

In 1992, revisions made officially by introduce the concept of corporate criminal liability. By the opinion of French lawmakers, the concept is more legally sensitive than the old and it because there is no effective way for France to be able to punish corporations for committing not commendable action. ${ }^{6}$

\section{c. Netherland}

The values of reparative or restorative justice in the Dutch criminal justice system can be seen in the mechanism of resolving cases outside the court (adoening buiten process) through discretionary authority possessed by the public prosecutor. ${ }^{7}$ The main principle that forms the basis of discretion for public prosecutors is the principle of opportunity (opportunitebeginel). This principle is interpreted internationally as "the public prosecutor may decide-conditionally or unconditinally- to make prosecution to court or not" ${ }^{8}$ Based on the provisions of Article 167 Wetbook van Straffvordering (the Dutch's Criminal Code) all prosecutors in the Dutch must decide to prosecute if the prosecution is considered important based on the investigation. But the prosecutor can stop the prosecution if the public interest views the case is better to stop the prosecution. Hence, the principle of

\footnotetext{
${ }^{1}$ Romli Atmasasmita, 2011, Sistem Peradilan Pidana Kontemporer, Jakarta: Kencana, p.126; Compared to Amir Ilyas, Asas-asas Hukum Pidana, memahami tindak pidana dan pertanggungjawaban pidana sebagai syarat pemidanaan. Yogyakarta: Rangkang Education, pp 34-35. ${ }^{2}$ Rule 1 (e) 1: "The attorney for goverment and the attorney for the defendant when acting pro se may engange in discussions with a view toward reaching an agreement that, upon the entering of a plea of gulity or nolo contendere to charged offense or to a lesser or related offense."

${ }^{3}$ Romli, Op.Cit, p. 127

${ }^{4}$ Rufinus Hotmaulana Hutauruk, 2014, Penanggulangan Kejahatan Korporasi Melalui Pendekatan Restoratif Suatu Terobosan Hukum. Jakarta : Sinar Grafika, p. 147

${ }_{6}^{5}$ Anwar Borahima. 2010. Kedudukan Yayasan di Indonesia (Eksistensi, Tujuan, dan Tanggung Jawab Yayasan). Jakarta: Kencana.

${ }^{6}$ Ibid

${ }^{7}$ Bambang Waluyo, op.cit, p. 179

${ }^{8}$ Andi Hamzah, 2012, Justice Collaborator atau Saksi Mahkota (Jurnal Bhina Adhyaksa Vol. VI No.1, Jakarta: Pusat Litbang Kejaksaan Agung, p. 13
} 
opportunity in the Dutch is not only the monopoly of the Attorney General as in Indonesia, but also the authority of every prosecutor.

Disregard of cases in the public interest in the Dutch can be done against ordinary crimes, in which the perpetrators are very old, even though the victim has been given compensation. ${ }^{1}$ Although the criminal law system in the Dutch has not yet set the restorative approach institutionally, but in the Dutch criminal code, there are several forms of alternative sanctions, includes: ${ }^{2}$

1) The alternative (HALT) $)^{3}$ is a special alternative sanction if the police can propose to the young offender to follow the healing process through a program to avoid a prosecution process and to them offered a job or compensation for losses for a maximum of 20 hours.

2) Community service is a community service given as compensation of other criminal sanctions, and it is expected to be able to build a sense of responsibility of the perpetrators. The types of service undertaken must be able to promote the interests of the wider community and educational-valued.

3) Work to compensate for damage incurred, where the character of the connection between criminal acts and the damage incurred must be made explicit in the series.

4) Learning schemes. The type of learning to be applied is adjusted to the nature or character of the crime that has been committed.

According to the researcher, a restorative approach in the Dutch legal system is applied by focusing on the aspects of prevention and recovery to every legal subject without exception, including corporations.

\section{d. Japan}

The Japanese criminal justice model is known as a dual track system, which is a restorative and traditional process will coexist together and where the parties determine the process of a particular case. If agreement in a restorative process cannot be reached (by consensus of all interested parties) then the criminal justice system will remain available. In this case, a restorative approach is placed in the primary position while the formal institutions have role as a supporting element. ${ }^{4}$

The Japanese's court officials (police, prosecutors, lawyers and judges) encourage actions that support the adoption of restorative values clearly by giving opportunities to victims and offender determine whether the case is proceeded to a formal process or alternatively to an informal process. They encourage offender to admit their mistakes and express deep regret for their mistakes and it is proven by restitution. The communities are encouraged to reintegrate the perpetrators who have regretted their mistakes. In addition, considers considering the nature and severity of violations when deciding on formal actions, and what must be taken for a particular offender. $^{5}$

The Japanese criminal justice model is a dual track system that uses formal and informal processes. Victims and offender have the opportunity to take actions that allow them to decide on the end of their conflict. The restorative values of encounters, participation, restitution, acceptance of responsibilities and opportunities for reconciliation are strongly emphasized by the availability of formal justice forums. ${ }^{6}$

\section{Proposed Concept of Corporation Punishment of Corruption Crime}

A main essence in eradicating corruption is the spirit of restoring State losses. It is clearly seen from the regulation of the State's right to file a civil suit against convicted assets which should be suspected comes from corruption crime. It shows how the legislators want a recovery of the consequences incurred from corruption crime.

According to the researcher, it is very limited if the recovery is only based on the State's financial losses or economy. In essence, the State's financial losses or economy are not limited to the value of money, but also to the damage incurred by corruption crime. Measurement of criminal effectiveness is often associated with the goals or results to be achieved. It is similar for determining the effectiveness of the legal system in general. According to Antony Allot, a legal system is a purpose system. Therefore, to measure its effectiveness it must be seen how far the legal system can realize or achieve its goals. ${ }^{7}$

As result of research findings, sanctions in the form of additional penalties (restitution) only exist in the Corruption Crime Acts, and it is not found in other laws and regulations. Therefore, additional penalties in the

\footnotetext{
${ }^{1}$ RM. Surahman, 1996, Mozaik Hukum, Jakarta: Sumber Ilmu Jaya, p. 72

${ }^{2}$ Annemieke Wolthuis, Restorative Aspects in The Dutch Juvenile Justice System, Defence for Children International Afdeling Netherland, Amsterdam, http://iirp.org/library.html. Downloaded on 27 July 2017

${ }^{3}$ HALT is an acronym for alternative in settlement as a revision of the provision of criminal law for young.

${ }^{4}$ Loc.Cit.

${ }^{5}$ Ibid, p. 143

${ }^{6}$ Yohanis Sudiman Bakti, 2015, Penerapan Prinsip Keadilan Restoratif dalam Proses Penyelesaian Perkara Pidana Anak, (Dissertation), Makassar: Postgraduate of Law Faculty, Hasanuddin University, p. 156

${ }^{7}$ Barda Nawawi Arief, 2000, Kebijakan Legislatif dalam Penanggulangan Kejahatan dengan Pidana Penjara, Semarang : Badan Penerbit Undip, p.96
} 
form of restitution for State as incurred from corruption crime are an attractive sanction to be observed. Thus, this legislation becomes the only instrument that is very effective to recover losses incurred of corruption crime, and until then becomes the only effective way to achieve the purpose of punishment in terms of recovering or restoring state financial losses (restitution). In achieving the recovering of financial or economic loss of a country, punishment plays an important role.

Based on data from the Director of the Prosecution of the Deputy Attorney for Special Crimes, Sugeng Purnomo that efforts to recover financial or economic losses of a country through the implementation of the decision have not been running optimally. This can be seen from the data regarding additional penalties from corruption crime cases from the last 3 years, it obtained from the data of the Attorney General of Republic of Indonesia per 31 December 2016 (Table 2).

Table 2. Data of restitution for 2016-2018 (In IDR)

\begin{tabular}{ccccc}
\hline Year & Case decision & Payment & Settlement without paying $^{1}$ & Arrear \\
\hline 2016 & 1.548 .230 .192 .611 & 343.675 .737 .270 & 560.967 .339 .512 & 643.587 .115 .829 \\
2017 & 1.173 .185 .109 .119 & 734.084 .662 .657 & 324.345 .552 .112 & 114.754 .894 .350 \\
2018 & 1.177 .903 .328 .509 & 842.864 .684 .734 & 691.918 .696 .989 & 43.912540 .967 \\
\hline
\end{tabular}

Source: The Deputy Attorney General for Special Crimes of the Republic of Indonesia

Based on the table above, the percentage of restitution as decided by the court from corruption in 2016 was only $22.2 \%$. In 2017 , the percentage of restitution as decided by the court from corruption was only $62.57 \%$, while in 2018 was only $71.56 \%$. From these data, the percentage of restitution through additional penalties from 2016 to 2017 is still far from the value of losses resulting from corruption crime, although from year to year increase, from $22.2 \%$ to $71,56 \%$.

In the draft of the Criminal Code, additional penalties are the implementation of customary law obligations. In customary law, there is a reaction and balance. The reaction is restoring balance. It is an entrance to reparation, long before we recognize a restorative justice. The existence of customary law is a restoration of a damaged balance, as a basis for reparation.

Punishment becomes plural and balanced between retributive, restorative and utilitarian. It is intended to punish the offender proportionally in accordance with the level of guilt. It is not only restorative because it can repair a loss incurred as a result of a crime, but it can also provide greater benefits for victims and the community and the environment that is damaged from the crime. ${ }^{2}$

The existing reparative value as in the principle of restorative justice is very likely to be applied to corporate punishment, as with the philosophy of Indonesian traditional law, that is to restore balance. Western criminal law is to determine who loses, who wins, whether guilty or innocent, customary law is more than just that. The customary law thinks about next, after being declared or pleading guilty, how the continuity to improve the victim. In line with the theory of utilitarianism that law must be useful, as well as the theory of progressive law that that law for society.

The punishment for future no speaks again who is wrong and right? However, an ideal punishment is a punishment that resolves the problems incurred by a criminal offense, to restore the balance that has arisen and creates a harmony. The ultimate goal of law is justice and harmony not certainty. It is in line with the goal of life in religion, to achieve happiness. How to give happiness, which the community must be happy because the roads, bridges, schools, good market, but because corruption causing it is not implemented, it will be restored. In imposing punishment for closing all or part of a company, it is very important to considers the interests of workers who are not directly involved and do not know anything about criminal acts committed by corporations.

According to the researcher, the addition of the phrase "... if assets are not found to be confiscated, the corporation is closed for a certain time" that has not been contained in the Corruption Crime Acts or the Regulation of Supreme Court No. 13 of 2016 is very important to be held. It is intended to anticipate situations where the prosecutor does not find or cannot identify corporate property or the corporation cannot pay in full or the confiscated asset is insufficient to restitution, hence the corporation can be convicted by close the company in a certain period as specified in the decision.

\section{Conclusion}

Reparative value is very likely to be applied in the punishment if it is already regulated in the statutory norms, by consider the philosophy of eradicating corruption crime to return the financial losses and economy of a country. Today, the reparative value as contained in corruption crime acts for corporations is still limited to additional penalties, namely substitute money. In practice, it is not effective, a more progressive punishment is needed that

\footnotetext{
${ }^{1}$ The amount of the restitution (substitute money) is stated finish because the defendant underwent a substitute criminal subsidair and the principal sentence was supported by a certificate from the Correctional Institution, death and the delegation of billing from the Special Crimes to the Civil and Administrative Affairs of the Republic of Indonesia Prosecutor General

${ }^{2}$ Indonesia Corruption Watch, Op.Cit, p.53
} 
can effectively restore the original state of the impact of the corruption crime.

The principle of restorative is a reparative justice, encounter conception, and transformative conception. Reparative justice or recovery to the victims or recovery to the consequences incurred of a criminal offense. Encounter conception is a way or process, to realize transformative conception, to achieving a just society by understanding the needs of all parties. But the essence of all is the intention of the perpetrators to admit their mistakes and its implementation in an effort to restore and repair the situation. The essence of reparation as a basic principle of restorative justice in corruption crime is to restore balance, the recovery of damage incurred due to corruption, so it needs to be formulated as an alternative additional penalty besides the restitution in the future.

\section{References}

Andi Hamzah, 2012, Justice Collaborator atau Saksi Mahkota. Jurnal Bhina Adhyaksa Vol. 6 No.1.

Amir Ilyas, Asas-asas Hukum Pidana, memahami tindak pidana dan pertanggungjawaban pidana sebagai syarat pemidanaan. Yogyakarta: Rangkang Education.

Annemieke Wolthuis, Restorative Aspects in The Dutch Juvenile Justice System, Defence for Children International Afdeling Netherland, Amsterdam, http://iirp.org/library.html. Downloaded on 27 July 2017

Anwar Borahima. 2010. Kedudukan Yayasan di Indonesia (Eksistensi, Tujuan, dan Tanggung Jawab Yayasan). Jakarta: Kencana.

Bambang Waluyo, 2016, Penegakan Hukum di Indonesia, Jakarta: Sinar Grafika.

Barda Nawawi Arief, 2000, Kebijakan Legislatif dalam Penanggulangan Kejahatan dengan Pidana Penjara, Semarang : Badan Penerbit Undip.

Indonesia Corruption Watch, 2015, Naskah akademik dan Rancangan Undang-Undang tentang Pemberantasan Tindak Pidana Korupsi, Jakarta.

Johny Ibrahim, 2006, Teori dan Metodologi Penelitian Hukum Normatif, Malang: Bayumedia.

Kristina, 2016, Pemberantasan Tindak Pidana Korupsi (Perspektif Hukum Progresif), Yogyakarta: Thafa Media.

Moh. Mahfud MD, Sunaryati Hartono, Sidharta, Bernard L. Tanya, Anton F. Susanto, 2013 Dekonstruksi dan Gerakan Pemikiran Hukum Progresif (Inaugural Speech Dr. Niken Savitri, SH, MCL; Teori Hukum Feminis dan Hukum Progresif), Yogyakarta : Tafa Media.

Muhammad Irwan, Slamet Sampurno Soewondo, M. Syukri Akub, Wiwie Heryani. 2018. The Role of Judges in Realizing Justice: A Criminal Justice Perspective. Journal of Law, Policy and Globalization, Vol. 76, 114.

RM. Surahman, 1996, Mozaik Hukum, Jakarta: Sumber Ilmu Jaya.

Romli Atmasasmita, 2011, Sistem Peradilan Pidana Kontemporer, Jakarta: Kencana.

Rufinus Hotmaulana Hutauruk, 2014, Penanggulangan Kejahatan Korporasi Melalui Pendekatan Restoratif Suatu Terobosan Hukum. Jakarta : Sinar Grafika.

Sharfudin, 2009, "Pelaksanaan Politik Hukum Pidana dalam Penegakan Hukum Pidana di Indonesia", Jurnal Hukum Pro Justitia Vol. 27 No.2.

Yohanis Sudiman Bakti, 2015, Penerapan Prinsip Keadilan Restoratif dalam Proses Penyelesaian Perkara Pidana Anak, Dissertation, Makassar: Postgraduate of Law Faculty, Hasanuddin University. 